\title{
IDENTIFYING AREAS OF KNOWLEDGE GOVERNANCE FOR SUCCESSFUL PROJECTS
}

\author{
Saumyendu Ghosh ${ }^{1}$, Lenis Amaya ${ }^{2}$, Mirosław J. Skibniewski ${ }^{3}$ \\ Department of Civil \& Environmental Engineering, University of Maryland, College Park, \\ 1188 G.L. Martin Hall, MD 20742-3021, USA \\ E-mail: ${ }^{1}$ Sghosh12@umd.edu (corresponding author) \\ Received 29 Sep. 2011; accepted 04 Apr. 2012
}

\begin{abstract}
Projects undertaken in the project-based industry are characterized by multiple stakeholders, uncertainty, and complexity due to the unique nature of each project. These differences also extend to knowledge movement from one project to another. Increased knowledge creation resulting from project implementation is expected to lead to numerous benefits. These benefits encompass reusability of lessons learned, as well as knowledge of strategic, operational, organizational, and managerial aspects of the firm. By adopting a unified knowledge creation framework, firms seek tangible and intangible benefits such as cost reduction, improved productivity, enhanced efficiency, and business growth. A case study was used to identify problem areas of knowledge creation and align corporate and project objectives. Incorporating a comprehensive knowledge creation plan in the organizational memory infrastructure can be a significant stride toward improving overall project management efficiency and increasing the organization's productivity and profitability in the industry. This stream of research will allow researchers to further refine knowledge creation success models. The paper will also draw practitioners' attention to areas where investment is needed to improve the knowledge governance process.
\end{abstract}

Keywords: organizational memory, project memory, project governance, knowledge governance, architecture and engineering consulting (AEC).

\section{Introduction}

Innovative knowledge assets are generally a key determinant of an organization's economic performance (Yang et al. 2010; He, Wang 2009). The need to retain knowledge within the organization and focus on continuous knowledge development throughout all levels of the organization is becoming a primary challenge in order to promote a competitive advantage at the organizational level (Johannessenm 2008; Liebowitz 1999).

Project memory, defined as "lessons and experiences from given projects", is not integrated into organizational memory (refer to Monticolo et al. (2007) for a detailed discussion) models. Project organizations (Tourtier 1995; Bekhti, Matta 2003; Bakker 2010) are temporary in nature and not aligned with project memory models. However, a project, being a temporary organization (Söderlund 2004), cannot use conventional organizational wisdom to protect knowledge created by the previous project (Greenberg, Roseman 2003; Wooldridge 2009). So, we consider it crucial that project memory based knowledge is used and produced during the entire project life cycle. Despite a recent surge in publications on this topic, there have been few attempts to align knowledge creation with organizational objectives.

\section{Knowledge governance for projects}

Knowledge governance requires a distinct approach based on organization theory and flow of knowledge.
Accurately defining the structure of organizational knowledge is crucial for effective project execution. It is necessary to understand who is responsible and accountable for knowledge creation related to a project and aligning it with corporate objectives. There is a growing need to ensure that there is a structure in place, within organizations, that delineates the responsibilities and ownership for determination of the strategic objectives of knowledge creation and align it with organizational and project goals. It is also clear that besides the effectiveness and efficiency of the execution of the strategy, accountability of the executives' actions must be considered.

This article aims to develop an understanding of how organizations can derive more value from participating in inter-organizational learning collaborations - with two organizations involved in the ecosystem, the project organization and the organization which owns the project organization. The project organization is temporary in nature while the organization owning the project is dynamic in nature; therefore, an understanding is needed for collaboration between the two organizations and viewed as one "level" within an extended organizational learning system (van Winkelen 2010). Nonetheless, with the emergence of knowledge-based economies, technology transfer models have been gradually developed by management researchers to explain the dynamic role of knowledge underlying the technology as the organizations' strategic asset and organizational learning through inter-firm technology transfer (Sazali et al. 2011). 
Holmqvist's (1999) model is used as a baseline to understand knowledge creation in the projects context consisting of project, organization and inter-organization context.

The model is based on how organizations should introduce knowledge creation structures that can be run in parallel with the organizational structure, in the pursuit of making more efficient and effective decisions, which is just one part of many such governance responsibilities. The model discusses relationships between different entities within the organizational structure and the impact of knowledge creation on other structural entities of the organization. The challenge for organizations will be to reconcile the internal knowledge management with the governance structure so knowledge creation is aligned with organizational strategic objectives. Architecture and engineering consulting (AEC) is the largest segment within the project based industry. Although adopting a project based approach may hold the promise of significant increase in productivity and profitability, data shows that these systemic innovations diffuse slowly in projectbased industries (Taylor, Levitt 2004). In organizations with more advanced team learning behavior, a positive relationship between learning orientation and creativity was attenuated at higher levels of learning orientation (Fong et al. 2007; Hirst et al. 2009).

\section{Research gaps}

Interdependency and knowledge complexity related to projects (Ghosh, Skibniewski 2010) caused by specialization had an important interacting effect on the relationship between coordination and knowledge sharing (Willem, Buelens 2009). However, as indicated in the knowledge governance section, knowledge movement is diverse, requiring strategic institutionalization to be effective, which is difficult in a temporary organization or in project settings. There is an abundance of literature in knowledge management for projects, focusing tools, and technique of knowledge creation and distribution. As a cross-functional participant, project governance protects the corporate body's strategic goals and objectives, and arranges the necessary environment to harvest and accomplish tactical plans. There have been very limited studies in investigating knowledge management in the project governance domain, or exploring the integrated applications of knowledge related variables which directly contribute to the success of projects, i.e., the strategic and tactical impact on project success. Current literature is based on the "how" part of knowledge creation rather than on "when and why". Our study tries to better understand when and why dimensions of knowledge creation required for making project governance successful in aligning with directions and controls of project governance and strategic organizational objectives which can directly impact the execution of the project.

There are two paradigms of research here - knowledge capture in a temporary environment, and improving project execution efficiencies with the help of knowledge captured in previous projects. The knowledge capture process mainly creates a platform for projects and creates a knowledge capturing stream, without any emphasis on how it will impact best practices later.

Organizations don't really work well without any defined objectives and goals for organizational efficiency. In fact, integration of knowledge capture best practices in a project environment is usually left entirely at the project level. Often organizational processes are also very deficient in defining processes in project environments due to excessive investments needed to define and execute process and regulatory strategies when cross-entities within an organization are involved. Therefore, execution of best practices strategy should take over the knowledge capture strategy. Project governance helps developing and managing a comprehensive strategy and recommends taking a collaborative or partner approach between different organizational entities.

Given the large body of knowledge on project success and governance, we think that this is a significant void in existing literature. There are two specific research questions:

1. What are the characteristics of knowledge movement aligning with project objectives?

2. What are the focus areas where investments are needed to improve the knowledge governance process in order to align it with project objectives?

\section{Research methodology}

Case study is a methodology when a holistic, in-depth investigation is needed (Feagin et al. 1991). Research in project based industries, especially related to modeling and integration of knowledge, has produced new technologies (Lytras et al. 2008) and capabilities to assist with construction engineering activities (Tatum 2011) and professional services products (Koch 2004). This paper focused on streamlining the creation of such knowledge. Organizational memory is perhaps most clearly missing in industries where large numbers of people engage in the design and construction of large, complex systems over long periods of time (Greenberg, Roseman 2003; Wooldridge 2009).

The contribution of the paper therefore lies in organizing the literature around the knowledge transfer processes in AEC organizations, in providing conceptual clarification of the knowledge movement process, and in identifying the project-based organizational memory elements so that a model can be formulated. A multinational AEC firm is chosen to understand flow of knowledge between different entities.

\section{Organizational learning and memory models}

Organizational memory is the means by which knowledge from the past is brought to bear on present activities, thus resulting in higher levels of organizational effectiveness. It plays an important role in encoding knowledge acquired by different learning routines, or in storage and effective use of knowledge (Atwood 2002). The nature of organizational learning in a particular industry will depend on factors such as firm size, a firm's 
underlying "cultural" assumptions and values, and the dominant competitive environment.

Organizational memory will enhance the organization's competitiveness (Brooking 1999; Kim et al. 2003; Tan et al. 2007) by improving knowledge creation (Clark et al. 2002). Mapping, supporting, sharing, and reuse of individual and organizational knowledge and lessons learned are at the core of a learning organization (Wexler 2001). It is supported by intelligent knowledge management services actively providing any user working on a project with the information required to fulfill the desired objectives (Koniger, Janowitz 1995; White 2002).

Knowledge management is defined as the control of the organizational problem solution (Rwelamila, Edries 2007) and adaptation capacity through a goal-directed development and utilization of the organizational knowledge base, and is considered to be an essential capability in the emerging knowledge economy. In particular, organizations have a valuable asset in the informal knowledge that is the daily currency of their knowledge workers, but this asset usually lives only in the collective human memory, and thus, is poorly preserved and managed. There are significant technical and cultural barriers to capturing informal knowledge and making it explicit (Weinberger, Frank 2006).

The knowledge can be in the form of largely undocumented experience, insights, knowledge, and skills acquired over the years, passed on to newcomers through personal contacts, meetings, training courses, and mentoring relationships. Organizational memory can influence organizational efficiency as well as organizational competitiveness (Stein 1995).

\section{Knowledge creation in the project setting}

In a highly fragmented project-based setting where multiple stakeholders are at different phases of the project life cycle, various stakeholders take ownership of different aspects of an implementation project (Somers, Nelson 2004; Becker, Praest 2005). However, there is a lack of understanding of knowledge creation among different members of the eco-system (Skibniewski, Ghosh 2008; Helo et al. 2008). The lack of proper use of organizational memory leads the organization to waste resources in rediscovering old solutions they applied years ago (Leonardi 2007). Also, it can lead to huge ongoing penalties, since organizations never regain the benefits of the solutions they once had. The obvious remedy is a permanent repository of the ongoing collected wisdom of the organization.

Identification, creation, development, dissemination, utilization, and preservation of knowledge in the firm have been identified as basic knowledge management activities (Abecker, Decker 1999). For knowledgecreation in networks of organizations, a new dimension of knowledge creation is needed. Holmqvist (1999) presents an extension to the organizational knowledge-creation model. He suggests that in networks of organizations, not only knowledge conversions between individual knowledge and organizational knowledge, but also transitions between the two, and inter-organizational know- ledge must be studied (Fig. 1). To coordinate actions in inter-organizational networks, the knowledge of individuals and single organizations must be modified to support the collaboration of a network. Inter-organizational knowledge consists of mutual knowledge unique to the collaboration and is independent of any single organization's knowledge.

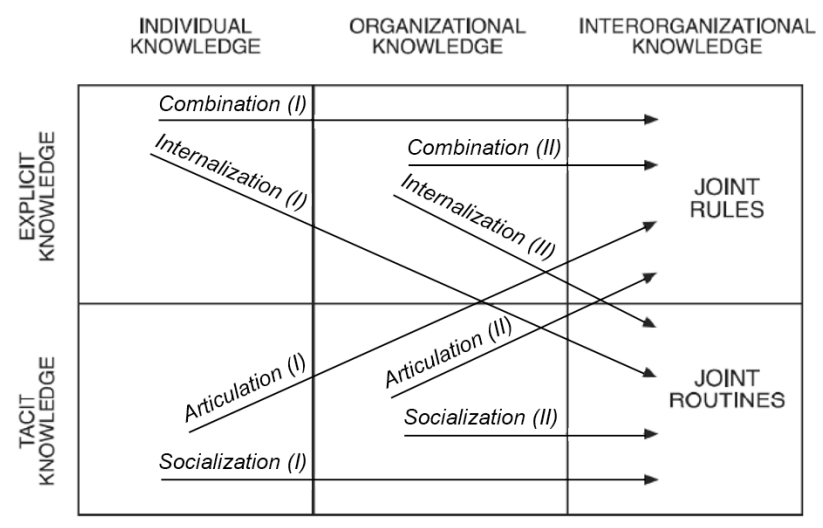

Fig. 1. Framework of learning in inter-organizational knowledge-creation (adapted from Holmqvist (1999))

Holmqvist (1999) added the dimension of interorganizational interactions to the knowledge spiral, arguing that in networks, the source of innovation is twofold. First, individuals within the network may collaborate and work closely on a project, having opportunities to create mutual tacit knowledge (Koenig, Srikantaiah 2003). In these situations they are also forced to articulate what they individually take for granted, given the diverse backgrounds of involved actors. Second, knowledge related to an organization's rules and routines may be tacitly transferred between members of different organizational actors. The presence of "outsiders" may also force reflection of tacit organizational routines and articulation of tacit organizational knowledge into explicit inter-organizational knowledge.

\section{Case study}

Major issues drawn from a big-picture analysis of knowledge management in the project based industry should be reachable with a more in-depth study of a specific firm. As discussed in Fig. 1, a network is needed to support knowledge creation but has not been aligned with the organizational success criterion. AEC organizations provide planning, design, and supervision for engineering projects ranging from factory manufacturing to highway construction (Ho, Chen 2001). In order to address the issues in the implementation of organizational memory model in an AEC organization, a case study was conducted. The AEC industry business process is project based with multiple parties involved, including owners, general contractors (GC), architects, engineers, sub-contractors, and material suppliers. The different organizational entities, i.e. project participants, follow different business processes and have different corporate goals to accomplish in the project. This abundance of disintegrated 
information and its time-sensitiveness in the AEC industry makes projects complex to manage and therefore we did not expect it to be mandatory for all the stakeholders to adopt the new technology but expected that most will do so to increase acceptance, which will ensure that the deployment of new technology is considered successful. However, in a highly fragmented AEC setting where numerous stakeholders come and go as the project proceeds, there has to be a different paradigm that incorporates knowledge input from end users so that project is governed better and more informed.

There is no study till date that has focused on the knowledge management aspects of project governance. Our goal in this study is to offer practical insights to AEC stakeholders where many of the end users might not be experts in project management but potentially benefit by using such a governance infrastructure. We believe that this study provides a basic mechanism for predicting successful knowledge creation from multidimensional perspectives.

The case study was conducted based on semistructured phone interviews with 35 project managers or higher ranking professionals from all the three countries where the organization has a presence. We also reviewed internal documents related to research for the case study. The interviews and reviewed documents address a wide range of topics including evaluation of knowledge movement related to the organization's structure (organizational and relationship), strategy (long term and short term), maturity (skills, process and leadership), and resource (both human and infrastructure) situation that may impact success of the project. Results were validated using triangulation method.

\subsection{Organization - current status}

This selected firm was founded in 1990, and consists of three offices in Venezuela, Colombia, and Nicaragua. Projects undertaken by this firm are mainly concentrated in these three countries and are related to infrastructure projects, technical assistance, instrumentation and control assistance, design and construction projects, among others. The firm is structured around a number of departments that serve one purpose. The selected organization performs multidisciplinary projects at the stages of conceptual engineering, both basic and detailed, and is specialized in the areas of instrumentation, process control, and automation. It also provides technical assistance services, monitoring and quality assurance, procurement, construction management and inspection, and personnel training.

Engineering work consists of calculation, research, and technical designs undertaken by engineers to produce the documents requested. Most of the detail work is based on documented best practices but not updated based on lessons learned from projects executed by the firm. However, several decisions are based on non documented methods and personal preferences, and better practical methods that exist, but are not well documented for all users.

The firm was chosen due to current problems that they thought they had solved in the past, and are challenging their current staff. Information is getting lost, and is hard to locate, or not properly saved. In the organization, currently, there is no procedure that adequately collects and saves a project's information for further use or consulting.

Currently, all projects developed in Colombia and Nicaragua is managed from the Venezuelan office. The project team on site gathers all the necessary project information and shares it with the team located in Venezuela. They work together to execute the project on time, on budget, and with the desired specifications. Since the work is executed between two locations, information gets lost or is not received on time. Also, further clarifications or extra information may be needed, which delays the delivery of scheduled products.

A project creates several deliverables and collaterals. Minutes of meetings, presentations to users, management, or steering committees, requirements documents, models, source code, build reports, issues logs, defects, and e-mail discussions are stored in the corporate network. Knowledge creation is not structured and therefore presents an opportunity for optimization. The dataprocessing structure exists, but must be adapted and increased for the knowledge management.

However, the firm does not have any process to store and index collaterals or use any version control software. There are no collaterals related to the selling strategy of the project. Sales teams that worked on a project previously are not reused as a unit.

Team members from a completed project are usually needed for the next project, and their new team leaders therefore recruit them into new teams as soon as possible. Given these constraints, it is rarely possible for all team members to undertake a systematic review of a completed project and document the knowledge and experiences derived from it.

Knowledge can be gained from lessons learned at sites which are not always connected to computers and the internet. Knowledge created at the construction site is translated into lessons that engineers can take into consideration in future designs. Site engineers report problems through emails to all the stakeholders. Gathering and managing this type of knowledge is a good step toward eliminating design errors. Engineer help is basically knowledge gained from other engineers that faced similar problems. This kind of knowledge can be acquired through informal communication channels and is not captured and shared throughout the organization.

The loss of project memory arises naturally through the turnover of people. Younger staff members were never aware of the issues, while their older colleagues have retired or moved on to other roles in the organization. This is why a structured project memory model is really needed in this organization, so everybody in the organization can find the information needed, no matter if they are new hires or people with tenure in the organization assigned to a new project.

Project memory loss is also noted when the same department or division forgets the knowledge it gained from previous experiences or projects. As a result, project resources tend to reinvent the wheel every time a new, yet in many respects similar, project is undertaken. 
From the previously explained facts, it is clear that the concept of "organizational memory" or "project memory" is not well understood and the firm needs to properly collect all the relevant information from every project they execute in order to enhance their technical skills and store them in a manner that will speed up future work, and produce high quality projects and in less time.

\subsection{Case study analysis}

Table 1 summarizes all the key observations made in the case study. Due to quick growth in the firm, there were no investments in sustainable knowledge creation activities. Members of the firm were not aware of the strategic and tactical direction the firm was headed. The inability to understand the value the firm would bring to new clients negatively impacted the firm's market share. A clear direction in the firm's strategic position in the marketplace and the firm's completion of projects in line with such strategic projects can positively impact ability to get new business and the firm's ability to sell to new projects.

Project information is rarely captured, retained, or indexed so that people external to the project can retrieve and apply it to future tasks. To address the issue of capturing a comprehensive project history that can subsequently be retrieved and applied to current problems, an organizational memory model should be developed to help to guide information retention and transfer. This impacted the firm's ability to reuse technical knowledge acquired in previous projects to improve current deliverables and save clients cost.

The firm was in need of improving and ensuring unanimity of purpose within the organization as well facilitating and specifying organizational purposes, and then translating these purposes into objectives so as to assess and control cost, time, and performance parameters.

The firm stressed the importance of establishing an organizational climate which was a key element in improving organizational efficiency. The firm does not have any firm wide organizational resource allocation process. Without this formal resource allocation process, planning and decision making was ad-hoc and not based on resource's skills or availability. This firm executes projects in different countries with different partners. The advantages of a learning process that takes place within the organization can be immensely multiplied when one considers the opportunities for organizations to learn from other organizations.

The success of a project is not only measured in costs and progress. A performance evaluation system was introduced whereby staff recognition was promoted and communication improved so as to motivate staff to do their best and to follow industry best practices.

Evaluation of all the environmental factors involved in the project is critical and necessary (Kuriakose et al. 2002) to provide the firm with a competitive advantage in the industry and is not transparent to the employees

Table 1. Summary of organizational memory based learning mechanism - observations

\begin{tabular}{|c|c|c|c|c|}
\hline Observation & $\begin{array}{l}\text { Examples from } \\
\text { the case study }\end{array}$ & $\begin{array}{l}\text { General observations } \\
\text { from case study }\end{array}$ & $\begin{array}{c}\text { Organization based learning } \\
\text { observations }\end{array}$ & Model specifications \\
\hline 1 & $\begin{array}{l}\text { "Each engineer adds his } \\
\text { own input when a prob- } \\
\text { lem arises based on his } \\
\text { past experiences" }\end{array}$ & $\begin{array}{l}\text { Several decisions are } \\
\text { based on non docu- } \\
\text { mented methods and } \\
\text { personal preferences }\end{array}$ & $\begin{array}{l}\text { Sharing experiences and } \\
\text { knowledge greatly reduces } \\
\text { the time and cost required to } \\
\text { solve similar recurring prob- } \\
\text { lems }\end{array}$ & $\begin{array}{l}\text { The project team uses an } \\
\text { input-output process to } \\
\text { resolve problems (decision } \\
\text { scenario and team and } \\
\text { individual learning) }\end{array}$ \\
\hline 2 & $\begin{array}{l}\text { "Lessons learned from } \\
\text { executed projects are not } \\
\text { always documented and } \\
\text { reviewed for the team and } \\
\text { the organization" }\end{array}$ & $\begin{array}{l}\text { Better practical } \\
\text { methods exist, but are } \\
\text { not well documented } \\
\text { for all users }\end{array}$ & $\begin{array}{l}\text { Supporting, sharing, and } \\
\text { reusing individual and orga- } \\
\text { nizational knowledge and } \\
\text { lessons learned are at the core } \\
\text { of a learning organization }\end{array}$ & $\begin{array}{l}\text { Collaboration is the key to } \\
\text { retrieve, link, organize, } \\
\text { preserve, and share infor- } \\
\text { mation to support collabora- } \\
\text { tive activities that can be } \\
\text { applied to future tasks }\end{array}$ \\
\hline 3 & $\begin{array}{l}\text { "Project information is } \\
\text { stored in the server, from } \\
\text { the first information given } \\
\text { by the client, to the final } \\
\text { deliverable information" }\end{array}$ & $\begin{array}{l}\text { Data available from } \\
\text { all the projects exe- } \\
\text { cuted by the firm are } \\
\text { stored in the firm's } \\
\text { server }\end{array}$ & $\begin{array}{l}\text { An effective management } \\
\text { information system provides } \\
\text { information on the past, pre- } \\
\text { sent and future of a project, } \\
\text { and on relevant events inside } \\
\text { and outside the organization }\end{array}$ & $\begin{array}{l}\text { Memory / project infor- } \\
\text { mation storage captures } \\
\text { information that must be } \\
\text { organized in ways that } \\
\text { create and preserve coher- } \\
\text { ence and search-ability }\end{array}$ \\
\hline 4 & $\begin{array}{l}\text { "A firm that is growing } \\
\text { needs to constantly up- } \\
\text { grade its storage capacity } \\
\text { structure to accommodate } \\
\text { increasing knowledge } \\
\text { creation demands" }\end{array}$ & $\begin{array}{l}\text { The data-processing } \\
\text { structure exists, but } \\
\text { must be adapted and } \\
\text { increased for } \\
\text { knowledge manage- } \\
\text { ment }\end{array}$ & $\begin{array}{l}\text { Organizational memory sys- } \\
\text { tem structure intends to pro- } \\
\text { vide information and to cap- } \\
\text { ture and disseminate the } \\
\text { knowledge within the organi- } \\
\text { zation as it grows }\end{array}$ & $\begin{array}{l}\text { Freedom to propose, up- } \\
\text { dates, and replace infor- } \\
\text { mation according to the } \\
\text { storage capacity structure } \\
\text { needs }\end{array}$ \\
\hline 5 & $\begin{array}{l}\text { "Currently, the firm exe- } \\
\text { cutes projects in different } \\
\text { countries, which makes } \\
\text { difficult to share infor- } \\
\text { mation and make deci- } \\
\text { sions in a timely manner" }\end{array}$ & $\begin{array}{l}\text { Work is executed } \\
\text { between two loca- } \\
\text { tions; information } \\
\text { gets lost or is not } \\
\text { received on time }\end{array}$ & $\begin{array}{l}\text { Organizational effectiveness } \\
\text { and competitive-ness is in- } \\
\text { creased by actively providing } \\
\text { any user working on any } \\
\text { project with the information } \\
\text { required in order to fulfill the } \\
\text { desired objectives }\end{array}$ & $\begin{array}{l}\text { Cross functional team ap- } \\
\text { proach to process infor- } \\
\text { mation, combine resources, } \\
\text { and solve problems at mul- } \\
\text { tiple levels of the project in } \\
\text { a timely manner }\end{array}$ \\
\hline
\end{tabular}


(Grant 1997). It follows that adaptation to new information technologies such as knowledge sharing systems (Pan, Scarbrough 1999), inevitably require a redefinition of the relationship between organization strategy and knowledge management with the use of technology in the firm.

The organization's lack of structured knowledge management strategies resulted in serious underutilization of knowledge resources, as strategic decisions get made without full appreciation of the actual ability of the organization to compete in a certain area of knowledge. In some situations, there is an overestimation of the depth or breadth of organizational knowledge that the organization possesses compared to the desired competitive position, resulting in an impaired ability to attain that position.

Discovering this at a time when things can still be saved is not enough since the cost of acquiring the requisite knowledge resources will undermine profits. On the other end of the spectrum are organizations that underestimate their knowledge and as a result lose many opportunities to capitalize on these resources. What makes this more eminent is that knowledge as a resource has a short life cycle and can be rendered obsolete in a short time if not grown and developed.

Written policies, standards, guidelines, procedures, tools, and techniques, when kept up-to-date, serve as the core of organizational memory. A younger staff member consulting such material discovers how the organization has already dealt with some issue. If that solution seems obsolete or inappropriate in today's environment, then he or she is free to propose an update or replacement solution.

Project information is rarely captured, retained, or indexed so that people external to the project can retrieve and apply it to future tasks (Weiser, Morrison 1998). Capturing a comprehensive project history that can subsequently be retrieved and applied to current problems helps guide information retention and the transfer process.

Knowledge management in AEC organizations is often a complex task. This is because project teams often consist of people with diverse skills working together for a limited period of time, a project team often includes members who have never worked together previously and do not expect to work together again.

A failure to practice effective knowledge management means that many AEC organizations are unable to appraise projects and learn from them. At its simplest, a failure to review a finished project means that the past errors are likely to be repeated. In some cases, these organizations can fail to learn from their mistakes for years on end (Boddie 1987).

Based on the analysis, we conclude that a structured approach is required to acquire project knowledge which can used in the future and add value to the firm's business process.

\section{Impact on project governance}

\subsection{Gap in the knowledge movement}

Gap in the knowledge movement is presented in Fig. 2. An assessment of how well the organizational knowledge creation model is aligned with the project governance

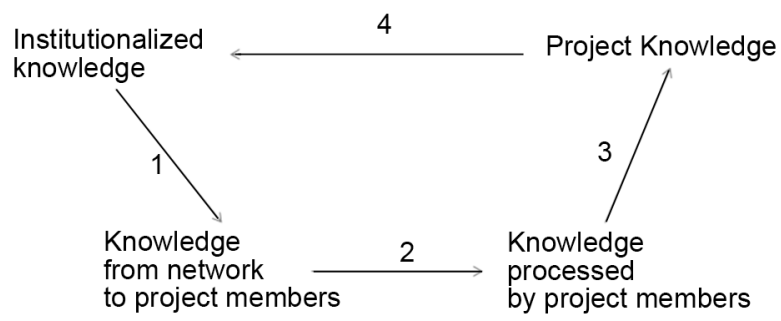

Fig. 2. A general model of project based organization's knowledge ecology

mechanism can be made using Fig. 2 (following sociologist Coleman (1999), Foss (2007)). And success should be measured by the outcome of such a mechanism in place. Based on the case, we can utilize Fig. 2 to identify the organizational capabilities and strategic alignment required in a governance framework. Currently, within the organization discussed, there are no conceivable mechanisms in the place of arrow 1 and arrow 4 . The reason is a fundamentally ontological and explosive growth in the organization without proper infrastructure in place. The knowledge movements can be attributed to macro mechanisms (i.e. arrows 1 and 4) and micro mechanisms (i.e. arrows 2 and 3). The diagram also helps us understand how governance would impact knowledge movement. In general, knowledge movement is affected by organizational antecedents. Considering that strategic movement of knowledge is manifested by arrow 1, the project should be aligned with organizational objectives, which are accomplished if proper mission management goals are setup. Similarly, arrow 4 indicated the organization's ability to absorb project collaterals so that it can be used by future projects. It is clear from the case that the movement depicted by arrow 2 is occurring. Arrow 3 exists in the firm, but is un-structured, impacting arrow 4 from being institutionalized. The firm should develop capabilities and conceivable mechanisms to construct project knowledge to the organizational level (Foss 2007).

\subsection{Analysis of knowledge movement impacting project governance}

The organization has not adopted inclusive knowledge environments (Ghosh et al. 2011a, b) (consisting of arrows 1 and 4 in Fig. 2) to compensate for project oriented entities in an effort to accomplish the strategic objectives of the business. Participation is required for the governance process to be effective and ensure the success of the project.

The firm did not setup any mission management objectives for strategically directing, supporting, and controlling the project and its management. These set of activities can be included by planning the transformation of project collaterals created from projects based on adequate strategy and well-defined methodology of implementation for the project, which will help align the project with corporate objectives. The firm's business in each country and project strategic directions were not aligned. This lack of integrated business process across countries did not facilitate business process engineering 
in identifying best practices and change management. There was also no cross functional team management to provide an integrated platform to deal with the challenge of laying the framework in which functional areas can operate in unison. No platform was built to institutionalize a platform for conscious and unavoidable reflection, a forum for exchange and discourse, without preempting either concrete outcomes or non-reflective prescriptions. This firm, although had grown in a short period of time without building organizational capabilities to support and manage cross functional team issues. There was no institutionalized effort to involve lessons learned from stakeholders and actors or to build trust (Girmscheid, Brockmann 2010) in the organization.

\subsection{Managerial relevance statement}

We believe that this research carries considerable implications in the context of knowledge movement in projects. To ensure governance effectiveness (Botman, Jager 2002), the proposed model is based on two objectives: defined relationship between the two tracks and ensure adoption of knowledge capture in the project context to support best practices. Project governance has become an increasingly effective center of efficient project execution and substantial performance allocation in all areas of project management, direction setting, decision making, and alignment with corporate project objectives. By embracing pluralism, project management research may be better equipped to explore and explain difficulties in project execution (Söderlund 2011). This article extends the concept of pluralism to the knowledge capture area as well. The relationship between knowledge capture and project governance is based on four key factors: the position of knowledge capture in the project life cycle, the alignment of knowledge capture with organizational strategy, the institutionalized ties with organizational strategy, and the principle of non-inference between knowledge capture and best practices, i.e. knowledge capture will support best practices, not vice versa.

What are the characteristics of knowledge movement aligned with project objectives? Since all projects are unique, they pose some unique challenges working with several stakeholders (Skibniewski, Ghosh 2009) and a complex integration process (Ghosh et al. 2011b). Managing knowledge effectively is critical to the survival and advancement of any organization, especially in project-based industries (Kivrak et al. 2008). This research explores the success variables inherent in project-based industries in adopting an enterprise knowledge solution model to facilitate project governance (Foss, Michailova 2009). Expanding our understanding of this phenomenon is critical as firms and industries continue to evolve into project-based forms of organization. Therefore, the understanding garnered from the AEC industry will help understand the project based industry and can be applied to other industries. However, the issue of knowledge management for the project based industry cannot be resolved using an organization memory model alone. Therefore, we adopted an approach to align the organizational memory model with project and organization su- ccess measures, and propose a knowledge governance approach.

What are the focus areas where investments are needed to improve the knowledge governance process so as to align it with project objectives? The article illustrates the need for an inclusive framework which is very useful for two distinct reasons. First, it can generate conciseness about the surroundings and institutionalize a structured way to capture knowledge from the stakeholders. The inclusive framework also provides an opportunity for stakeholders with relatively poor visibility (Renn 2005). Strategically, this should ensure capture of best practices. Second, an inclusive framework or "new institutionalism" generates awareness about the project and product or service produced in collective action and is likely to have better chances to ensure knowledge capture is complete. The approach also opens up an opportunity for the project owning organization to do many things, e.g. understanding pre-assessment of risks in the areas with least visibility, pre-emptive evaluation of a changing project situation, implementing regulatory changes early etc., and accordingly plan with impacted project resources for achieving other corporate goals and re-alignment.

The authors believe that knowledge capture only at the project level by itself is inadequate to explain all the challenges faced by the project organization as shown in the case study. This can be addressed in multiple areas. First, knowledge capture could be a very good way of aligning corporate strategies with project objectives. From the content aspect of knowledge capture, successful execution of project would depend on how process and best practices followed in the project aligns with corporate process and best practices. Each project, while unique in nature, cannot have its own best practices without any corporate sponsorship and alignment. Secondly, project organization is part of the larger organization. The knowledge capture process must be inclusive of any best practices followed by the larger organization.

\section{Conclusion and future research}

Our study tries to better understand the gap in the capabilities and infrastructure required to support a knowledge capture framework in project based industries. The problem with the project based industry are multi-fold - significant growth in the industry's delivery capacity without improvement in the support capabilities and lack of business processes to institutionalize a structured alignment of knowledge management with project execution strategy - which requires knowledge governance in place. The greatest obstacle to incorporating and institutionalizing a comprehensive knowledge governance framework is the lack of its strategic alignment to corporate goals, infrastructure and inability to understand return on investment. The largest subset of this industry is the small and medium sized organizations that have failed in their efforts to adopt technology integration in the business process governance (Neghaban 2008).

The concept of knowledge governance applied to project is not a recent development, but aligning it with the organization's strategy is. Building a knowledge- 
friendly culture, one of the most important factors for a project's success, is one of the most difficult to create if it does not already exist (Cortada, Woods 1999). Therefore, organizations without formal knowledge governance in place, should adopt a project's focused "knowledge governance approach", which is characterized as a distinctive approach that cuts across the fields of knowledge management, organizational studies, and project ecology. Therefore, project knowledge governance will impact deployment of governance mechanisms, which influences project knowledge processes, such as "sharing, retaining and creating knowledge" (Foss 2007).

Future research should focus on developing tools and techniques to execute knowledge governance framework for projects, and validate them in the field. The gaps identified in the firm's knowledge movement (Fig. 2) will also need to be validated so that executives can institutionalize them in project organization settings.

\section{References}

Abecker, A.; Decker, S. 1999. Organizational memory: knowledge acquisition, integration, and retrieval issues, in XPS-99: Knowledge-based systems. Survey and Future Directions, Lecture Notes in Computer Science, Volume 1570, 113-124. http://dx.doi.org/10.1007/10703016_7

Atwood, M. 2002. Organizational memory systems: Challenges for information technology, in The $35^{\text {th }}$ Hawaii International Conference on systems sciences, 7-10 January, 2002, Hawaii, USA, 919-927.

Bakker, R. M. 2010. Taking stock of temporary organizational forms: A systematic review and research agenda, International Journal of Management Reviews 12(4): 466-486. http://dx.doi.org/10.1111/j.1468-2370.2010.00281.x

Becker, M.; Praest, M. 2005. Intra and inter-organizational knowledge transfer process: Identifying the missing links. Danish research unit for industrial dynamics, DRUID Working Paper No. 06-32, 47 p.

Bekhti, S.; Matta, N. 2003. Project memory: An approach of modelling and reusing the context and design rationale, in IJCAI-03, Knowledge Management and Organizational Memories workshop, 9-15 August, 2003, Acapulco, Mexico. 6 p.

Boddie, J. 1987. The project post-mortem, Computerworld 21(49): 77-82.

Botman, D.; Jager, H. 2002. Coordination of speculation, Journal of International Economics 58(1): 159-175. http://dx.doi.org/10.1016/S0022-1996(01)00166-0

Brooking, A. 1999. Corporate memory: strategies for knowledge management. International Thomson Business Press. $181 \mathrm{p}$.

Clark, M. A.; Amundson, S. D.; Cardy, R. L. 2002. Crossfunctional team decision-making and learning outcomes: A qualitative illustration, Journal of Business \& Management 8(3): 217-220.

Coleman, J. S. 1999. Foundations of social theory. Cambridge: The Belknap Press of Harvard University Press. 993 p.

Cortada, J. W.; Woods, J. A. (Eds.). 1999. The knowledge management yearbook 1999-2000. Knowledge Reader Series. Butterworth-Heinemann. 563 p.

Feagin, J.; Orum, A.; Sjoberg, G. 1991. A case for case study. Chapel Hill, NC: University of North Carolina Press. $290 \mathrm{p}$.
Fong, P. S.-W.; Hills, M. J.; Hayles, C. S. 2007. Dynamic knowledge creation through value management teams, Journal of Management in Engineering ASCE 23(1): 40-49. http://dx.doi.org/10.1061/(ASCE)0742-597X(2007)23: $1(40)$

Foss, N. J.; Michailova, S. 2009. Knowledge governance: Processes and perspectives. Oxford University Press. 304 p.

Foss, N. J. 2007. The emerging knowledge governance approach: challenges and characteristics, Organization 14(1): 29-52. http://dx.doi.org/10.1177/1350508407071859

Ghosh, S.; Skibniewski, M. J. 2010. Enterprise resource planning systems implementation as a complex project: A conceptual framework, Journal of Business Economics and Management 11(4): 533-549.

http://dx.doi.org/10.3846/jbem.2010.26

Ghosh, S.; Boswell, J. W.; Kwak, Y.-H.; Skibniewski, M. J. 2011a. Risk governance framework for enterprise-wide application implementations, in The 2011 IEEE International Technology Management Conference (ITMC), 932938.

Ghosh, S.; Negahban, S.; Kwak, Y.-H; Skibniewski, M. J. 2011b. Impact of sustainability on integration and interoperability between BIM and ERP - A governance framework, in The 2011 IEEE International Technology Management Conference (ITMC), 187-193.

Girmscheid, G.; Brockmann, C. 2010. Inter- and intraorganizational trust in international construction joint ventures, Journal of Construction Engineering and Management ASCE 136(3): 353-360.

http://dx.doi.org/10.1061/(ASCE)CO.1943-7862.0000142

Grant, R. 1997. The knowledge based view of the firm: Implications for management practice, Long Range Planning 30(3): 450-454. http://dx.doi.org/10.1016/S0024-6301(97)00025-3

Greenberg, S.; Roseman, M. 2003. Using a room metaphor to ease transitions in groupware, in Mark S. Ackerman, Volkmar Pipek, Volker Wulf (Eds.). Sharing expertise: beyond knowledge management. MIT Press, 203-256.

He, J.; Wang, H. C. 2009. Innovative knowledge assets and economic performance: The asymmetric roles on incentives and Monitoring, Academy of Management Journal 52(5): 919-938.

http://dx.doi.org/10.5465/AMJ.2009.44633414

Helo, P.; Anussornnitisarn, P.; Phusavat, K. 2008. Expectation and reality in ERP implementation: consultant and solution provider perspective, Industrial Management \& Data Systems 108(8): 1045-1059. http://dx.doi.org/10.1108/02635570810904604

Hirst, G.; Van Knippenberg, D.; Zhou, J. 2009. A cross-level perspective on employee creativity: goal orientation, team learning behavior, and individual creativity, Academy of Management Journal 52(2): 280-293. http://dx.doi.org/10.5465/AMJ.2009.37308035

Ho, C.; Chen, J.-J. 2001. The case-based reasoning system for knowledge management of engineering consulting projects, in Proc. of The International Conference on Computational Intelligence for Modeling Control and Automation and International Conference on Intelligent Agents Web Technologies and International Commerce (CIMCA'06), November 28-December 1, 2006, Sydney, Australia, 234.

Holmqvist, M. 1999. Learning in imaginary organizations: creating interorganizational knowledge, Journal of Organizational Change Management 12(5): 419-438. http://dx.doi.org/10.1108/09534819910289101 
Johannessen, J.-A. 2008. Organisational innovation as part of knowledge management, International Journal of Information Management 28(5): 403-412.

http://dx.doi.org/10.1016/j.ijinfomgt.2008.04.007

Kim, S.; Suh, E.; Hwang, H. 2003. Building the knowledge map: an industrial case study, Journal of Knowledge Management 7(2): 34-45.

http://dx.doi.org/10.1108/13673270310477270

Kivrak, S.; Arslan, G.; Dikmen, I.; Birgonul, M. T. 2008. Capturing knowledge in construction projects: knowledge platform for contractors, Journal of Management in Engineering ASCE 24(2): 87-95. http://dx.doi.org/10.1061/ (ASCE)0742-597X(2008)24:2(87)

Koch, C. 2004. The tyranny of projects: teamworking, knowledge production and management in consulting engineering, Economic and Industrial Democracy 25(2): 277-300.

Koenig, M.; Srikantaiah, T. K. 2003. Knowledge management lessons learned: What works and what doesn't. ASIS Monograph series. Information Today Inc. 550 p.

Koniger, P.; Janowitz, K. 1995. Drowning in information, but thirsty for knowledge, International Journal of Information Management 15(1): 5-16.

http://dx.doi.org/10.1016/0268-4012(94)00002-B

Kuriakose, K.; Seetha, H.; Murty, S. 2002. From management of organizational knowledge to management of organizational memory, in Proc. of The 32nd Annual Hawaii International Conference on System Sciences, 5-8 January, 1999, Maui, HI, USA, 12-24.

Leonardi, P. M. 2007. Activating informational capabilities of information technology for organizational change, Organization Science 18(5): 813-831.

http://dx.doi.org/10.1287/orsc.1070.0284

Liebowitz, J. 1999. Knowledge management handbook: Collaboration and social networking. $2^{\text {nd }}$ Ed. CRC Press. $328 \mathrm{p}$.

Lytras, M.; Russ, M.; Maier, R.; Naeve, A. 2008. Knowledge management strategies. A handbook of applied technologies. IGI Global. $390 \mathrm{p}$.

http://dx.doi.org/10.4018/978-1-59904-603-7

Monticolo, D.; Hilaire, V.; Koukam, A.; Gomes, S. 2007. Ontodesign; A domain ontology for building and exploiting project memories in product design projects. CoDeKF Project. 6 p.

Neghaban, S. 2008. Utilization of enterprise resource planning tools by small to medium size construction organizations: A decision-making model. PhD Thesis, University of Maryland, College Park.

Pan, S. L.; Scarbrough, H. 1999. Knowledge management in practice: An exploratory case study, Technology Analysis and Strategic Management 11(3): 359-374.

http://dx.doi.org/10.1080/095373299107401

Renn, O. 2005. Risk Governance towards an integrative approach, international risk governance council. White paper, Geneva [cited Sept 19, 2011]. Available from Internet: $<$ http://www.irgc.org $>$.

Rwelamila, P. D.; Edries, R. 2007. Project procurement competence and knowledge base of civil engineering consultants: An empirical study, Journal of Management in Engineering ASCE 23(4): 182-192. http://dx.doi.org/10. 1061/(ASCE)0742-597X(2007)23:4(182)

Sazali, A. W.; Haslinda, A.; Jegak, U.; Raduan, C. R. 2011. Evolution and development of technology transfer models and the influence of knowledge-based view and organiza- tional learning on technology transfer, Research Journal of International Studies (12): 79-91.

Skibniewski, M. J.; Ghosh, S. 2008. Identifying elements of enterprise wide application selection eco-system, in The 25th International Symposium on Automation and Robotics in Construction, 26-29 June, 2008, Vilnius, Lithuania, 810-816.

Skibniewski, M. J.; Ghosh, S. 2009. Determination of key performance indicators with enterprise resource planning systems in engineering construction firms, Journal of Construction Engineering and Management ASCE 135(10): 965-979. http://dx.doi.org/10.1061/(ASCE) 0733-9364(2009)135:10(965)

Söderlund, J. 2004. Building theories of project management: past research, questions for the future, International Journal of Project Management 22(3): 183-191. http://dx.doi.org/10.1016/S0263-7863(03)00070-X

Söderlund, J. 2011. Pluralism in project management: Navigating the crossroads of specialization and fragmentation, International Journal of Management Reviews 13(2): 153-176. http://dx.doi.org/10.1111/j.1468-2370.2010. 00290.x

Somers, T. M.; Nelson, K. G. 2004. A taxonomy of players and activities across the ERP project life cycle, Information \& Management 41(3): 257-278.

http://dx.doi.org/10.1016/S0378-7206(03)00023-5

Stein, E. W. 1995. Organizational memory: Review of concepts and recommendations for management, International Journal of Information Management 15(1): 17-35. http://dx.doi.org/10.1016/0268-4012(94)00003-C

Tan, H. C.; Carrillo, P. M.; Anumba, C. J.; Bouchlaghem, N. D.; Kamara, J. M.; Udeaja, C. E. 2007. Development of a methodology for live capture and reuse of project knowledge in construction, Journal of Management in Engineering ASCE 23(1): 18-26. http://dx.doi.org/ 10.1061/(ASCE)0742-597X(2007)23:1(18)

Tatum, C. B. 2011. Core elements of construction engineering knowledge for project and career success, Journal of Construction Engineering and Management ASCE 137(10): 745-750. http://dx.doi.org/10.1061/(ASCE)CO.1943-7862.0000306

Taylor, J. E.; Levitt, R. E. 2004. Understanding and managing systemic innovation in project-based industries. Stanford University Publication. 17 p.

Tourtier, P. A. 1995. Analyse préliminaire des métiers et de leurs interactions [Preliminary analysis of trades and their interactions]. Rapport intermédiaire [interim report], project GENIE, INRIA-Dassault-Aviation, 1995. 25 p.

van Winkelen, van C. 2010. Deriving value from interorganizational learning collaborations, The Learning Organization 17(1): 8-23. http://dx.doi.org/10.1108/09696471011008215

Weinberger, A.; Frank, A. 2006. Evaluating organizational memory: A three-layer model, in F. Lehner, H. Nosekabel, P. Kleinschmidt (Eds.). Multikonferenz Wirtschaftsinformatik [Economics and Computer Science]. Berlin: GITO-Verlag. Series on Knowledge Management in Research and in the Industry, Vol. 2, 487-499.

Weiser, M.; Morrison, J. 1998. Project memory: management for project teams, Journal of Management Information Systems 14(4): 149-166.

Wexler, M. N. 2001. The who, what and why of knowledge mapping, Journal of Knowledge Management 5(3): 249264. http://dx.doi.org/10.1108/EUM0000000005868 
White, D. 2002. Knowledge mapping and management. IRM Press. 375 p.

Willem, A.; Buelens, M. 2009. Knowledge sharing in inter-unit cooperative episodes: The impact of organizational structure dimensions, International Journal of Information Management 29(2): 151-160.

http://dx.doi.org/10.1016/j.ijinfomgt.2008.06.004
Wooldridge, M. 2009. An introduction to multi-agent systems. $2^{\text {nd }}$ Ed. Wiley. 484 p.

Yang, C.-W.; Fang, S.-C.; Lin, J. L. 2010. Organisational knowledge creation strategies: A conceptual framework, International Journal of Information Management 30(3): 231-238. http://dx.doi.org/10.1016/j.ijinfomgt.2009.08.005

Saumyendu GHOSH. An experienced program director with a large global consulting firm. He has worked on all the major market segments with extensive experience as program manager, solution architect, team lead and a delivery consultant. He is also a researcher on project governance theory with multiple publications on referred journals and international conferences; currently teaching project governance and international project management at George Washington University's business school.

Lenis AMAYA. Has master's degree in project management from A. James Clark School of Engineering at the University of Maryland, College Park, USA and currently working as a practicing project manager.

Miroslaw J. SKIBNIEWSKI. The A. James Clark Endowed Chair Professor of Project Management in the A. James Clark School of Engineering at the University of Maryland, College Park, USA. In addition to other former appointments at academic and government research institutions worldwide, he has been serving as a visiting professor in the Department of Management at Bialystok University of Technology in Poland. Among Prof. Skibniewski's honors are the U.S. National Science Foundation Presidential Young Investigator Award, Walter L. Huber Research Prize from the American Society of Civil Engineers, elected Foreign Membership in the Russian Academy of Engineering, and an honorary doctorate from Vilnius Gediminas Technical University in Lithuania. 